\title{
DEPRESSOR RESPONSE TO NORADRENALINE IN HYPOTHERMIC CATS
}

\author{
K. KAR, R.N. SUR AND S.N. PRADHAN* \\ Central Drug Research Institute, Lucknow, India
}

Reccived for publication August 19, 1968

\begin{abstract}
Although noradrenaline (NA) is well known for its pressor effect, it has been shown to produce a depressor response in hypothermic cats and $\operatorname{dogs}(1,2)$; the mechanism of the latter effect has, however, not yet been clearly elucidated. This effect has been attributed to its ganglion blocking action (1) as well as to the parasympathetic over-activity resulting from the altered state of the higher autonomic center during hypothermia (2). It was, therefore, the object of this study to investigate further the mechanism of this depressor response to NA during hypothermia.
\end{abstract}

\section{METHODS}

Thirty-seven cats of either sex weighing between $2-4 \mathrm{~kg}$ wcre anaesthetized with urethane $(1.75 \mathrm{~g} / \mathrm{kg})$ given intraperitoncally. Blood pressure was recorded from the carotid artery with a mercury manometer and the respiration through a tracheal cannula. 'The body temperature was noted from a thermometer inserted into the rectum. Surface cooling of the animals was done by putting them on a tray and packing them with ice. Prior to cooling, control recordings were made of the pressor responses to $1-2 \mu \mathrm{g} / \mathrm{kg}$ of NA and adrenaline (Adr) in all cats and of the depressor responses to the same doses of isoprenaline (IP) and acetylcholine (ACh) in 15 cats. The same doses of these drugs were repeated as the body temperature was being lowered upto $20^{\circ} \mathrm{C}$. Electrocardiogram (Lead II) of 4 anaesthetized hypothermic cats were recorded by means of Hellige Simpliscripter apparatus.

All compounds were injected through the femoral vein. The following compounds were used in these experiments:

a) Noradrenaline bitartrate (Unichem),

b) Adrenaline hydrochloride (May \& Baker),

c) Isoprenaline sulphate (Burroughs Wellcome \& Co.),

d) Acetylcholine chloride (B.D.H.),

c) Physostigmine salicylate (Smith T.H.),

f) Neostigmine bromide (Roche),

g) Atropine sulphate (Smith T.H.),

Communication No. 1299 from Central Drug Research Institute, Lucknow, India.

* Present addrcss: Professor of Pharmacology, Howard University, College of Medicine, Washington DC 200?l, U.S.A. 


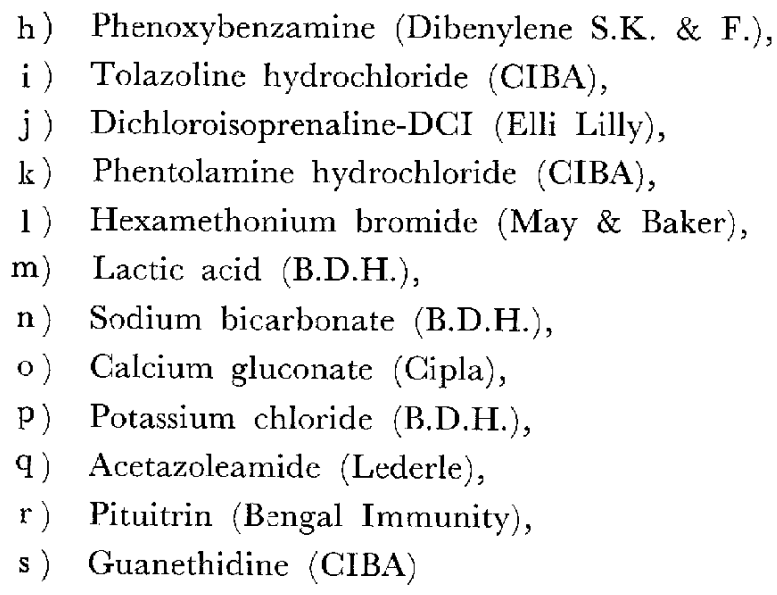

\section{RESULTS}

Responses of blood pressure to some autonomic drugs during hypothermia

In 37 normothermic (rectal temperature $37-39^{\circ} \mathrm{C}$ ) cats under urethane anaesthesia, blood pressure ranged from 80 to $120 \mathrm{~mm}$ of $\mathrm{Hg}$. In all these cats $\mathrm{NA}$ and $\mathrm{Adr}(1-2 \mathrm{~kg} / \mathrm{kg})$ showed the usual pressor response. With the decrease of temperature, the pressure gradually fell down to $30-20 \mathrm{~mm}$ of $\mathrm{Hg}$ and the responses to $\mathrm{NA}$ and Adr declined by $1-7 \mathrm{~mm}$ of $\mathrm{Hg}$ per degree fall of temperature. Finally during deep hypothermia (rectal temperature $27-20^{\circ} \mathrm{C}$ ) a depressor response to NA was observed in 26 out of 37 cats. In these cats the fall of blood pressure ranged from $8-32 \mathrm{~mm}$ (avcrage $16 \mathrm{~mm}$ ) of $\mathrm{Hg}$. The depressor response to NA gradually diminished with further lowering of temperature. In one of these 26 hypothermic cats blood pressurc was raised by a slow infusion of pituitrin $(0.1 \mathrm{unit} / \mathrm{kg})$ in normal saline; the depressor response to NA in this cat was more pronounced. In the remaining cats, the pressor response to $\mathrm{NA}$ was only reduced, but prolonged and never reversed. In all cats high doses $(10-20 \mu \mathrm{g} / \mathrm{kg})$ of $\mathrm{NA}$ and $\Lambda \mathrm{dr}$ also showed same pattern of response.

The depressor responses to ACh and IP (1-2 $\mu \mathrm{g} / \mathrm{kg})$ as observed in 15 normothermic cats, also decreased markedly during hypothermia when the blood pressurc level also gradually declined to $30-20 \mathrm{~mm}$ of $\mathrm{Hg}$.

Effects of various agents on the depressor responses to $N A$ and $A d r$

a) Adrenergic blocking agents: Three blockers of adrenergic $\alpha$-receptor, phenoxybenzamine, tolazoline and phentolaminc were administered in $5 \mathrm{mg} / \mathrm{kg}$ doses to different cats. They could neither reverse the pressor responses to NA in normothermic cats, nor potentiate the depressor responses to NA, Adr and IP during hypothermia. The depressor response to ACh was not affected. On the other hand, DGI, a $\beta$-receptor blocking agent $(3 \mathrm{mg} / \mathrm{kg}$ ) completely abolished the depressor responses to $\mathrm{N} \Lambda, \mathrm{Adr}$ and IP in $3 \mathrm{hy}-$ pothermic cats; the similar response to $\Lambda \mathrm{Ch}$ was again not affected.

b) Cholinergic and anti-cholinergic agents: A dose $(0.2-0.8 \mathrm{mg} / \mathrm{kg})$ of physostigmine or neostigmine that potentiated ACh-induced hypotension, reversed the depressor responsc 

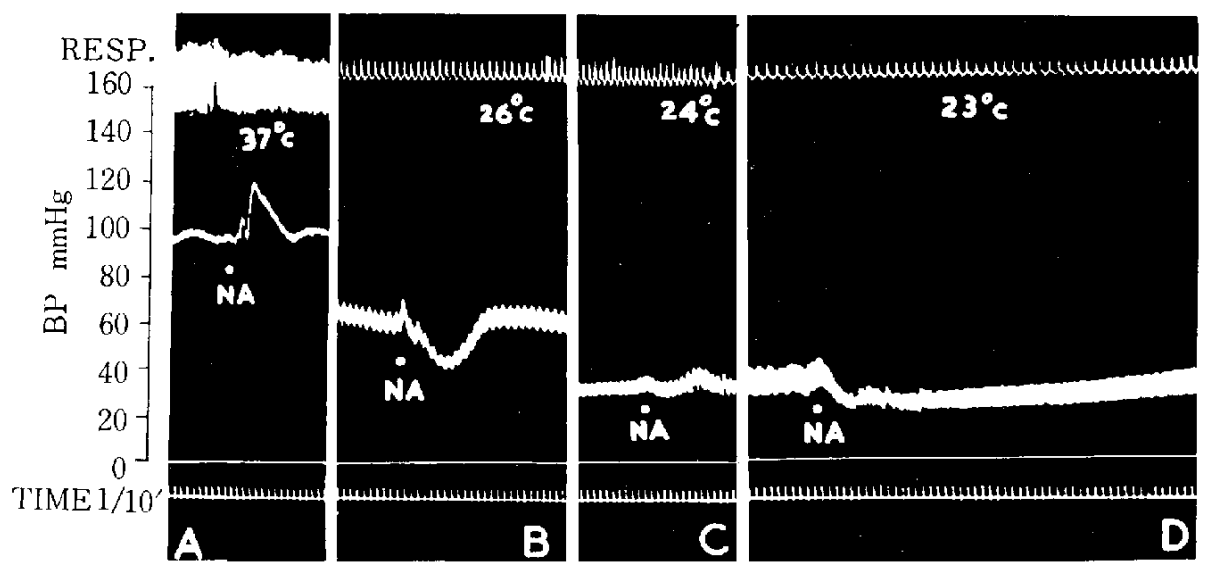

FIG. 1. Cat $3.8 \mathrm{~kg} f$. Urethane anaesthesia. The effect of noradrenaline (NA, $1 \mu \mathrm{g} / \mathrm{kg}$ ) on the blood pressure of hypothermic cat.

A : Shows pressor response to $\mathrm{NA}$ at $37^{\circ} \mathrm{C}$

$\mathrm{B}$ : Shows depressor response to $\mathrm{NA}$ at $26 \mathrm{C}$

C : Shows reduction of depressor response to $\mathrm{NA}$ at $24 \mathrm{C}$ after physostigmine $(0.3$ $\mathrm{mg} / \mathrm{kg}$ )

D : Shows re-establishment of depressor response to $\mathrm{NA}$ at $23^{\circ} \mathrm{C}$ after atropine sulphate (2 mg/kg)

to NA in 8 hypothermic cats. $A$ dose $(1-2 \mathrm{mg} / \mathrm{kg})$ of atropinc sulphate that could completely block $\Lambda$ Ch-induced hypotension, restored the depressor response to NA in these hypothermic cats (Fig. 1). Furthermore, following treatment with such doses of atropine, physostigmine $(0.8 \mathrm{mg} / \mathrm{kg})$ also partially reduced the depressor response to $\mathrm{N} \Lambda$. Likewise in two cats following treatment with guanethidine, a known adrenergic neuron blocking agent neostigmine reduces the magnitude of the depressor action of NA during hypothermia.

The electrocardiogram in Lead II was recordcd before and after the administration of NA in hypothermic cats. The result showed that NA caused bradycardia during hypothcrmia but it increased the heart rate by two or three beats per minutes when the rectal temperature reached the critical range of temperature $\left(23-20^{\circ} \mathrm{C}\right)$ and NA caused hypotension.

In neostigmine treated cats, $\mathrm{NA}$ failed to bring about any change in the heart rate even when the cat was having the critical range of rectal temperature and there was no vasodepressor action of $\mathrm{NA}$ in this cat.

c) Ganglion blocking agents: In three out of 5 cats the depressor response to NA during hypothermia remained unaffected following the administration of hexamethonium bromide $(10 \mathrm{mg} / \mathrm{kg})$ alone or in combination with the atropine sulphate $(1 \mathrm{mg} / \mathrm{kg})$. This NAinduced depressor response was blocked by DCI, a $\beta$-receptor blocking agent $(3 \mathrm{mg} / \mathrm{kg})$ (Fig. 2).

d) Miscellaneous agents: The vasodilator effect of $\mathrm{Adr}$ has been attributed to the accumulation of lactic acid in the skelctal muscle (3). Lactic acid, was therefore, administered in 2 of these cats that failed to show the depressor response to NA during hypother- 

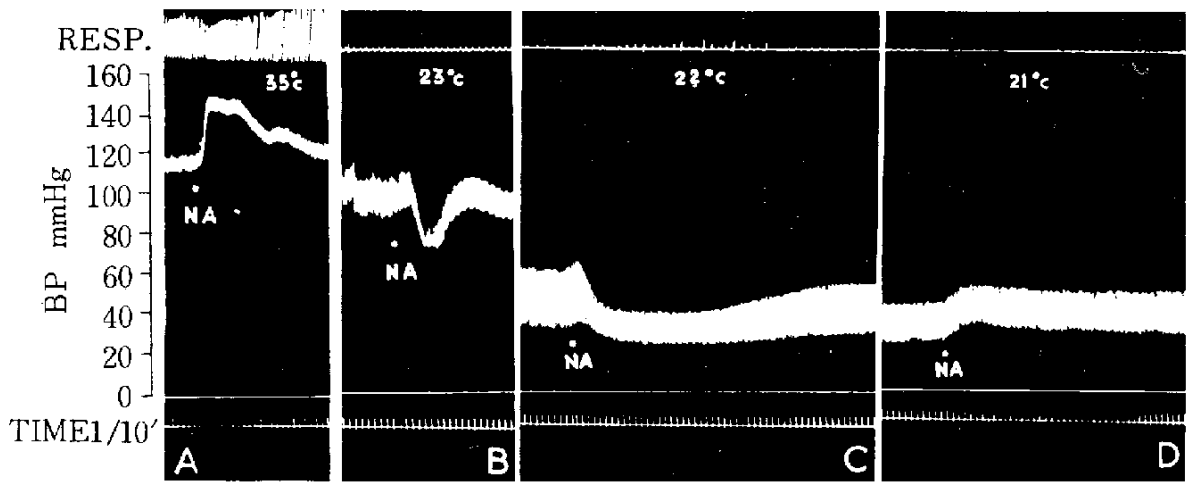

FIG. 2. Cat $2.6 \mathrm{~kg}$. . Urethane anaesthesia. The effect of noradrenaline $(\mathrm{NA}, 2 \mu \mathrm{g} / \mathrm{kg})$ on the blood pressure of atropinized hypothermic cat. Pressor response at $35^{\circ} \mathrm{C}(\mathrm{A})$, depressor response at $23^{\circ} \mathrm{C}$ (B) to $\mathrm{NA}$ bcforc hexamethonium and depressor response to $\mathrm{NA}$ (C) after hexamethonium $(10 \mathrm{mg} / \mathrm{kg})$ at $22^{\circ} \mathrm{C}$ DCI $(3 \mathrm{mg} / \mathrm{kg})$ blocks the depressor action of $\mathrm{NA}$ (D) at $21^{\circ} \mathrm{C}$.

mia; no hypotension could be induced in these cats. In another cat, lactic acid was infuscd at the rate of $10 \mathrm{mg} / \mathrm{kg} / \mathrm{min}$ for 5 minutes causing a slight rise of blood pressure. When the pressure returned to normal, the cat was injected with NA which also failed to induce the depressor response.

Acetazoleamide, a carbonic anhydrase inhibitor, was injected in a cat in $80 \mathrm{mg} / \mathrm{kg}$ dose to induce acidosis. No hypotension was seen in this cat during hypothermia following injection of $1-2 \mu \mathrm{g} / \mathrm{kg}$ of NA. Alternately, a solution of sodium bicarbonate $(166 \mathrm{mEq} /$ litrc) with potassium chloride $(0.7 \mathrm{mEq} / \mathrm{kg}$ ) and calcium gluconate (10\% solution $10 \mathrm{ml})$ was infused at the rate of $10 \mathrm{ml} / \mathrm{min}$ for 10 minutes (4) in 2 cats showing depressor response to NA during hypothermia. Following such infusion, the depressor response to NA could still be induced as usual.

\section{DISCUSSION}

Pamnani and Achar (1) observed depressor effect of NA in hypothermic dogs anaesthetized with pentobarbitone and artificially ventilated, and attributed this to a possible ganglion blocking action of NA. Dcy and Mukherjec (2) noted a similar response to NA in cats under urethane anaesthesia and artificial respiration at $22^{\circ} \mathrm{C}$, and proposed a central mechanism for this action. The present study confirms these observations by demonstrating the depressor response to NA in 26 out of 37 hypothermic cats anaesthetized with urethanc and not requring artificial respiration.

The present study indicates that this depressor response to $\mathrm{N} \Lambda$ during hypothermia could not be due to altcration of lactic acid content or $\mathrm{pH}$ of blood as proposed by Lundholm and Mohme-Lundholm (3) in case of $\mathrm{Adr}$-induced vasodilation. This response is also not due to active reflex vasodilatation as observed by Beck (5) and Sakuma and Beck (6) in the perfused hind quarter of normothermic dogs in response to NA and Adr. Such vasodilatation could neither be blocked by atropine nor potentiated by physostigmine (7), but could be abolished by local sympathectomy or by high doses of a ganglion blocking 
agent (5). Such active reflex vasodilatation thus differs from the depressor response to NA during hypothermia and does not therefore appear to contribute to the causation of the latter.

The depressor response to NA during hypothermia, however, has been successfully blocked by DCI, a $\beta$-receptor blocking agent. In this respect this response qualitatively resembles that shown by Adr (especially after administration of $\alpha$-receptor blocking agents) or IP, and thcrefore appears to be associated with the $\beta$-receptor activity. Had this depressor response been elicited by the ganglion blocking action or by the central parasympathetic over activity, as proposed by some workers $(1,2)$, it would not be liable to be blocked by DCI. It may be possible that the pressor responses to NA and Adr and to $\alpha$-receptor stimulation decreases with the progress of hypothermia, leaving the depressor response associated with the $\beta$-receptor activity unaffected. The latter response, though relatively unsusceptible to hypothermia also decreases with further lowering of body temperature.

Further, the depressor response to NA could be reduced or reversed by the anti-cholinestcrases, such as physostigmine or neostigmine and restored by the anticholinergic agent, atropine. These findings are in agreement with similar observations of Woodbury and Hiatt (8) with $\Lambda \mathrm{dr}$ after adrenergic blockade in normothermic dogs. Neostigmine has been shown to elicit pressor response following ganglion blockade in normothermic dogs, which could be blocked by atropine; the site for such actions of ncostigmine and atropine has been suggested to be autonomic ganglion (9). The ganglionic action of neostigmine or physostigminc is most unlikely because pretreatment of the animal with guanethidine did not affect the neostigminc or physostigmine induced rise of blood pressure. It may then be possible that while hypothermia causes bradycardia and diminishes the force of contraction of the myocardium, neostigmine or physostigmine slows the heart rate further and improves the cardiac output by increasing the stroke volume of the heart. NA under this condition fails to produce hypotension.

\section{SUMMARY}

1. The mechanism of depressor response to noradrenaline in hypothermic cats under urcthane anaesthesia but without artificial respiration has been studied.

2. The depressor response to noradrenaline has been completely blocked by dichloroisoprenaline, a known $\beta$-receptor blocking agent.

3. The depressor effect of noradrenaline in hypothermic cats has been reduced and reversed by physostigmine and neostigmine while atropine sulphate in appropriate dosage again restores the hypotensive effect of noradrenaline.

4. Hexamcthonium bromide, a ganglion blocking agent, alone or in combination with atropine sulphate fails to block such effect of noradrenaline in deep hypothermia.

5. Suggestions have becn made that pressor response to noradrcnaline due to $\alpha$-receptor activation is diminished and depressor responsc mediated by $\beta$-receptor is unmasked during hypothermia whereas physostigmine or neostigmine restores the pressor response to noradrenaline by pharmacological and physiological antagonism acting at some site on the myocardium. 
Acknowledgement: The authors are grateful to Dr. M.L. Dhar, Director, Central Drug Research Institute, Lucknow, India for his keen interest in this work and Dr. J.N. Sharma for his help in the initial stage-of this study.

\section{REFERENCES}

1) Pamnani, M.B. and Achar, M.V.S.: Ind. J. Med. Sci. 14, 937 (1960)

2) Dey, C.D. and Mukherjee, S.R.: J. exp. Med. Sci. 7, 1 (1963)

3) Lundholm, L. And Mohme-Lundholm, E.: CIBA Found. Symp. on "Adrenergic Mechanism", Edited by Vane, J.R., Wotstenholme, G.E.W. ant O'Connor, M., p. 305, Churchill, London (1960)

4) Kenyon, J.R., Ludbrook, J., Downs, A.R., Tait, 1.B., Brooks, D.K. and Pryczkowski, J.: Lancet 2, $41(1959)$

5) Веск, L.: Am. J. Physiol. 201, 123 (1961)

6) Sakuma, A. and Beck, L.: Am. J. Physiol. 201, 129 (1961)

7) Binet, L. and Burstein, M.: C. r. Seanc. soc. Biol. 141, 630 (1947)

8) Woodeury, R.A. and Hiatt, R.: Fedn Proc. 18, 461 (1959)

9) Hruton, J.G.: J. Pharmac. exp. Ther. 132, 23 (1961) 